
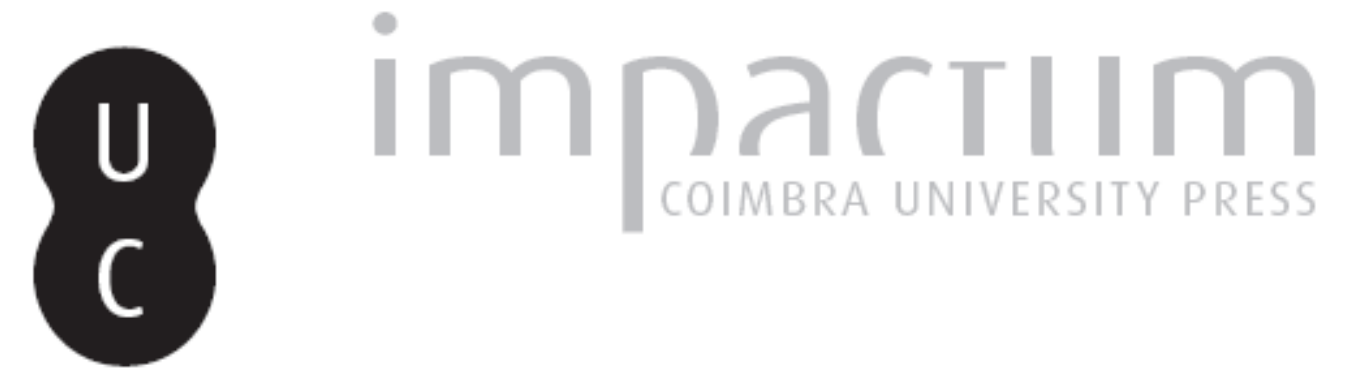

\title{
Plato's cosmological medicine in the discourse of Eryximachus in the Symposium: the responsibility of a harmonic techne
}
Autor(es):
Candiotto, Laura

Publicado por:

Sociedade Internacional de Platonistas; Imprensa da Universidade de Coimbra

URL persistente:

URI:http://hdl.handle.net/10316.2/38748

DOI:

DOI:http://dx.doi.org/10.14195/2183-4105_15_5

\section{Accessed : $\quad$ 26-Apr-2023 10:23:01}

A navegação consulta e descarregamento dos títulos inseridos nas Bibliotecas Digitais UC Digitalis, UC Pombalina e UC Impactum, pressupõem a aceitação plena e sem reservas dos Termos e Condições de Uso destas Bibliotecas Digitais, disponíveis em https://digitalis.uc.pt/pt-pt/termos.

Conforme exposto nos referidos Termos e Condições de Uso, o descarregamento de títulos de acesso restrito requer uma licença válida de autorização devendo o utilizador aceder ao(s) documento(s) a partir de um endereço de IP da instituição detentora da supramencionada licença.

Ao utilizador é apenas permitido o descarregamento para uso pessoal, pelo que o emprego do(s) título(s) descarregado(s) para outro fim, designadamente comercial, carece de autorização do respetivo autor ou editor da obra.

Na medida em que todas as obras da UC Digitalis se encontram protegidas pelo Código do Direito de Autor e Direitos Conexos e demais legislação aplicável, toda a cópia, parcial ou total, deste documento, nos casos em que é legalmente admitida, deverá conter ou fazer-se acompanhar por este aviso.

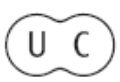


0

\section{Established 1989}

$\infty$ http://platosociety.org/

\section{Papers}

Thomas C. Brickhouse

Nicholas D. Smith

Socrates on the Emotions

Yosef Z. Liebersohn

Socrates, wake up! An analysis and exegesis of the "preface" in Plato's Crito (43a1-b9)

Nathalie Nercam

L'introduction problématique du Timée (17a-27a)

Christopher Moore

'Philosophy' in Plato's Phaedrus

Laura Candiotto

Plato's cosmological medicine in the discourse of Eryximachus in the Symposium. The responsibility of a harmonic technê

Anthony Hooper

Scaling the Ladder

Why the Final Step of the Lover's Ascent is a Generalizing Step

$\varangle$

Z
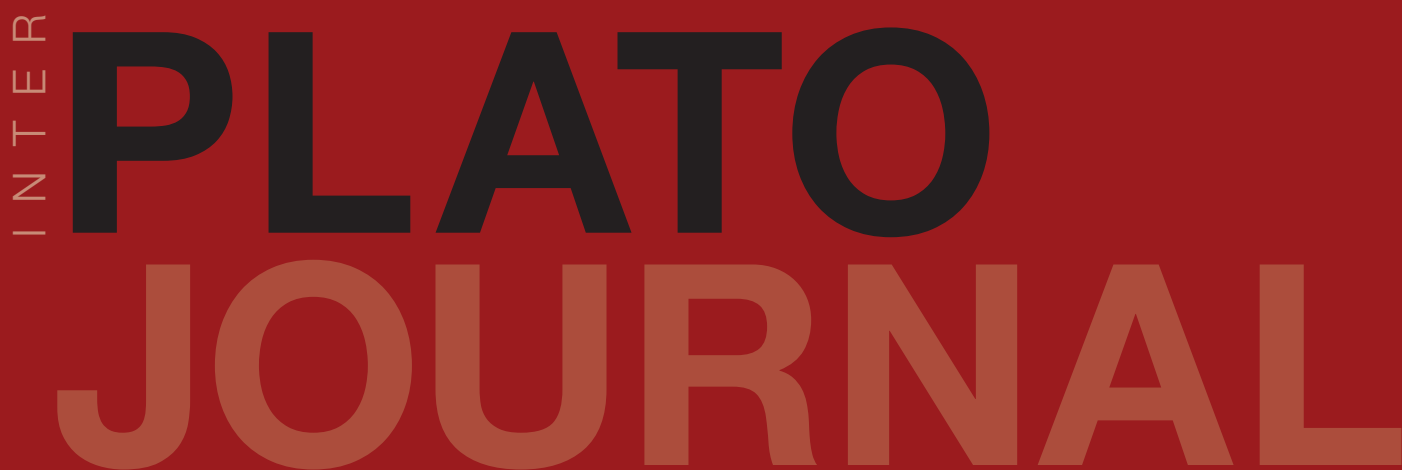

Société Platonicienne Internationale

Associazione Internazionale dei Platonisti

Sociedad Internacional de Platonistas

Internationale

Platon-Gesellschaft

Imprensa da

Universidade

de Coimbra

Coimbra

Universiy

Press 


\section{Plato's cosmological medicine in the discourse of Eryximachus in the Symposium. The responsibility of a harmonic technê}

\section{Laura Candiotto}

University of Edinburgh

Laura.Candiotto@ed.ac.uk

\section{ABSTRACT}

By comparing the role of harmony in Eryximachus' discourse (specifically in Symposium 187 a 1-188 a 1) with other Platonic passages, especially from the Timaeus, this article aims to provide textual evidence concerning Plato's conception of cosmological medicine as "harmonic technê". The comparison with other dialogues will enable us to demonstrate how Eryximachus' thesis is consistent with Plato's cosmology a cosmology which cannot be reduced to a physical conception of reality but represents the expression of a dialectical and erotic cosmos, characterized by the agreement of parts.

Arguably, Eryximachus' discourse is expression of the Platonic tendency to translate onto the philosophical plane the implications of a model peri physeôs. Harmonic technê is thus always linked to the theme of moral responsibility: the philosopher is also doctor, musician and demiurges in his harmonizing activity. The speech of Eryximachus can be approached as a Platonic step which is fundamental for establishing the need for a "medicine" to cure disorder, with a view to obtaining a cosmos ordered according to the harmonic principle.

Keywords : Plato's Symposium; Eryximachus; harmony; cosmological medicine; technê; education. 


\section{ERYXIMACHUS}

Eryximachus is a physikos belonging to a family of doctors (his father is Acumenus) whose members trace their origin back to Asclepius. As a Platonic character, we find him in - in addition to the Symposium - Protagoras 315 c 2, where he questions Hippias about nature, astronomy and meteorology. Moreover, he is cited in Phaedrus 268 a9 as Phaedrus's friend. ${ }^{1}$ An Eryximachus is cited among those who had desecrated the Herms in 415 , but it is not clear whether or not he is the Eryximachus that we are concerned with here.

In opposition to those who consider Eryximachus a pedant, ${ }^{2}$ whose discourse is refuted by Diotima's discourse, ${ }^{3}$ this paper proposes an interpretation emphasizing literary and philosophical aspects which enable us to grasp the positive significance carried by Eryximachus' discourse within the Symposium. ${ }^{4}$

Eryximachus represents temperance or we could say on the basis of what will be demonstrated below - the concept of harmony: as a symposiarch he decides the correct balance with respect to the proportions of water and wine (176 b 5-e 3), as a doctor he proposes a therapy for Aristophanes' hiccups (185 c 7-8), as a good musician he establishes the order of discourses and restores it after the disorder generated by Alcibiades' arrival (214 a 6-b 8). Arguably, by grasping these aspects, and connecting them to what we will say on the notion of cosmological medicine that emerges from his (Eryximachus') speech, it will be possible to question, at least partially, the assumption that Eryximachus' discourse is pedantic and sophistic.

\section{THE STRUCTURE OF ERYXIMACHUS' DISCOURSE}

Eryximachus's discourse can be subdivided into six sections: ${ }^{5}$

Prologue: Eryximachus refers to the discourse of Pausanias, saying that it is right to retain a double nature for Eros but that such double nature needs to be extended to the whole cosmos.

Section 1: Eros and medicine. The body manifests Eros' double nature in the coexistence of healthy desires and unhealthy desires. Medicine is the science of the erotic tendencies of the body to fill and empty itself. It enables the distinction between healthy and unhealthy desires. The task of the doctor is to transform the fight between the two Erotes in friendship by operating on opposites: cold/hot, bitter/ sweet, dry/humid.

Section 2: Eros and music. Eryximachus comments on Heraclitus' fragment DK 22 b51, interpreting it from a temporal perspective: the doctor musician is able to create harmony from an initial discord. He operates thus through a technique which is able to transform the discordant into concordant. Music is then the science of love of harmony and rhythm. It is important to take care of both forms of Eros, using cautiously that of the muse Polyhymnia, enjoying its pleasure without falling sick.

Section 3: Eros and meteorology and astronomy. Prosperity and Health happen when the opposites find themselves reciprocally united in an ordered love and support each other in harmony and temperate mixture. When excessive Eros prevails (ho meta tês hybreôs Eros), which 
leads to imbalance, we witness epidemics, disease and destruction.

Section 4: Eros and religion. Friendship between men and Gods happens by seconding ordered Eros.

Epilogue: Eryximachus concludes by saying that Eros possesses a universal power and that happiness comes from that Eros which aims at the good with justness and moderation. He then passes the baton to Aristophanes, inviting him to fill the gaps in his speech.

\section{THE CONCEPT OF HARMONY IN ERIXYMACHUS' PHYSICS}

By focusing on the relationship between philosophy and physics - particularly Heraclitus and Empedocles' physics - it is possible to individuate more clearly the Platonic position present in Eryximachus' discourse. This position differs from the pre-Socratic approach, and can be considered as Plato's particular interpretation of Greek medicine. In fact, medicine and philosophy emerge from the same cultural and professional substratum, with ample and persistent reciprocal influences. ${ }^{6}$ Hippocrates is Plato's contemporary, albeit younger. It is therefore easy to think that Plato, through Eryximachus, presents his interpretation of medical theory, establishing a dialogical relation with the Hippocratic Corpus. ${ }^{7}$ This approach is consistent with the method employed by Plato against tradition or against the dominant doctrines of his time: Plato develops his positions starting from these doctrines, but he rewrites them to his advantage, giving them a different interpretation. As discussed below, a clear example of this method is the Platonic interpretation of Heraclitus.
According to Eryximachus, nature is composed of opposite forces whose dynamics create movement and transformation. The doctor qua good physicist and knower of the cosmos must know the erotic tendencies of elements in order to help them to come together in relations of mutual friendship. In Eryximachus' discourse, which inherits Pausanias' conception of double Eros, Empedocles' two cosmic forces - philia and neikos - assume an immanent character as forces that compose nature in ordered and disordered forms. Equilibrium is dynamic: in Empedoclean terms, it is possible to maintain that the predominance of philia over neikos does not cancel out neikos but shapes it in the right proportion. Eryximachus thus transforms the Empedoclean perspective which defines the starting point of his discourse by emphasizing the necessary coexistence of the two forces. ${ }^{8}$ Such coexistence will not be conflictual as in Heraclitus, but it will unfold in harmonic proportion. Subsequently Eryximachus transforms Heraclitus' own maxim (DK 22, b51) to his own advantage.

[...] perhaps Heracleitus intends as much by those perplexing words, 'The One at variance with itself is drawn together, like harmony of bow or lyre.' Now it is perfectly absurd to speak of a harmony at variance, or as formed from things still varying. Perhaps he meant, however, that from the grave and acute which were varying before, but which afterwards came to agreement, the harmony was by musical art created. For surely there can be no harmony of acute and grave while still at variance: harmony is consonance, and consonance is a kind of agreement; and agreement of things varying, so long as they are at variance, is impossible. ${ }^{9}$ (trad. H. N. Fowler) 
This is one of the most commented-on passages of Eryximachus' speech, especially because it can be considered as one of the sources for reconstructing the Platonic interpretation of Heraclitus. In the context of this article, I would like to highlight the concept of harmony that is expressed here through a shift in the meaning of Heraclitus' utterance. Harmony is not realized by discordant things but by transforming discordant things into concordant ones. For Eryximachus, Heraclitus intended to say that harmony is realized by things that were previously discordant and that, thanks to medical praxis, become concordant. Harmony is in fact both consonance (symphônia), and agreement (homologia).

The word homologia is central to the dialogic-dialectical method developed by Plato, which here takes on a cosmic value, in the sense of erotic relationship between the parts that make up the physical universe. The "cosmological medicine" permeates every dimension of reality, emerging therefore as an ethical cosmos. ${ }^{10}$

Before analyzing the ethical relevance of the harmonic technique I would like to explore the theme of the specific form that the harmonic composition takes in Eryximachus's speech. The physics described by Eryximachus is not an ordered and harmonic whole but a world in movement and transformation that must be ordered by a doctor-demiurge following the principle of harmony.

Plato, reporting Heraclitus's thesis in the above-mentioned passage of the Symposium, uses sympheretai. This linguistic slippage is interesting from a semantic point of view and indicates, in my opinion, different ontological commitments: homologein indicates a convergence of logoi, an agreement more than identification; the sympheretai indicates a process of unification, the action of putting together $(s y n+$ pherô $)$ what is not together: the elements are held together by something else (the middle-passive form is used). In other fragments, however, we find the same sympheretai attributed to Heraclitus (DK 8), and this may suggest a general equivalence of the two terms in our author. However, in terms of the Platonic reception, it is interesting to underline that Plato interprets Heraclitus according to the sympheretai paradigm, and thus according to a process that holds together what is not together, namely the opposites.

In this way, Eryximachus emphasizes the role of technique and of human action in the universe. Such a role consists of creating a dynamic equilibrium by transforming discordant forces into concordant ones, without falling into the error of eliminating one of the two poles, but finding the right rhythm to enjoy the pleasure that the negative force offers whence a relation is established with the positive one. Moderation or temperance is thus not the dictatorship of the positive, but the right proportion between the different constituents of the universe, like the right proportion between water and wine to prevent intoxication, as explained by Eryximachus in $176 \mathrm{c}$ 1-e 3.

Rhythm, which transforms the fast and the slow from discordant to concordant, is realized thanks to numeric harmony.

[...] when a thing varies with no disability of agreement, then it may be harmonized; just as rhythm is produced by fast and slow, which in the beginning were at variance but later came to agree. ${ }^{11}$

From this perspective Eryximachus refers to the Pythagoreans, and, presumably, to Heraclitus, establishing a relation between the harmony which manifests itself in the cosmos and an "invisible" harmony. In fact it is the 
number, a being that is invisible yet present in the visible, which creates harmony within the proportional relation. Musical harmony, which can be perceived through the ears but which is realized through the numerical proportion between high-pitched and low-pitched sounds is thus the bond holding together body and soul, the sensible and ideas.

Conversely, celestial harmony does not possess the double nature of Eros: Eryximachus argues in fact that in harmony itself (thus in the idea of harmony) there is no duality (187 c5-7). Duality is rather the model according to which the musician-demiurge as good craftsman must order the opposite forces which are present in the physis.

[...] but when we come to the application of rhythm and harmony to social life, whether we construct what are called 'melodies' or render correctly, by what is known as 'training,' tunes and measures already constructed, we find here a certain difficulty and require a good craftsman. $^{12}$

The topic of the cosmological function of celestial harmony obviously recalls the Timaeus. This dialogue clearly explains that the harmony of the microcosm should be related to that of the macrocosm. Accordingly, the health of the body will be properly defined as the right equilibrium among elements (81 e 6-86 a 8), the health of the soul as the absence of excesses in the constitution of its nature, good education and mode of life. Music resolves the task of healing the soul by restoring the balance lost through incarnation:

[...] and then as much of the domain of the Muses as can be employed for the hearing of sound $\dagger$ was given for the sake of attu- nement. And attunement, whose movements are naturally akin to the circular motions of our souls, is useful to the man who makes intelligent use of the Muses not for mindless pleasure (which is nowadays taken to be the point of melody), but for the disharmony of the soul's revolutions that has arisen in us : attunement is an ally, provided by the Muses for the soul in its fight to restore itself to order and harmony. Rhythm also was given for the same purpose by the same benefactors, to support us because for the most part our internal state is inconsistent and graceless. ${ }^{13}$ (Tr. R. Waterfield)

The right proportion amongst elements is defined in the Timaeus as conformity to nature, imbalance as a disorder that creates illness in the body and the soul. In fact, nature has been created by the demiurge in the best possible way, yet it presents imbalances due to the disorder of elements in the chorr. This explains the necessity of the ordering role of a magistrate-demiurge who legislates, as well as the healing practice of a doctor who heals the soul and the body, taking as a model the constitution of the Universe. ${ }^{14}$

Eryximachus' discourse distinguishes the hidden harmony from harmonic actions: the doctor, like the divine craftsman, creates harmony in the sensible universe on the model of the intelligible using the "double Eros" as a force; the hidden harmony, which is not subject to duality, acts as a model for the harmonic action, in a typical Platonic copy-model system of participation. The medical-demiurgical-musical art thus implies the restoration of a hidden proportion. 


\section{THE ROLE OF EDUCATION IN THE COMPOSITION OF ELEMENTS}

Harmonic practice needs temperance as a law of composition. Eryximachus' discourse presents the theory of the composition of contraries, based on the law that "the similar loves the similar". ${ }^{15}$ Eryximachus therefore endorses the concept of harmony as unity of opposites, yet in a way different from Heraclitus: the unity in question is possible only if the opposites become friends, transforming their nature from that of discordant opposites to a composition of similar elements. ${ }^{16}$ A qualitative change takes place. Friendship does not imply a shift from opposition to identity, but from opposition to the proportion between similar elements. Proportion pertains in fact to the correct measure, the reciprocal relation between different elements. Through a quantitative transformation (in other words, by creating the right proportion) the contrasting relation between elements becomes harmonic. Elements change their oppositional qualities thanks to a quantitative change. For this reason Eryximachus maintains that Polyhymnian Eros must be retained but that its presence must be well proportioned in relation to that of Uranian Eros. The duality of Eros is therefore functional to the medical concept of harmonic proportion between elements.

Eryximachus' speech is not only theoretically - as well as chronologically — dependent on that of Pausanias: Eryximachus provides a medical justification of the force of love in nature, placing it in an ethical context. In the speech of Pausanias, Eros is understood in sexual terms: "noble Eros" gives education in exchange for the erotic relationship, whilst "base Eros" only exploits sexually the body of the beloved. In Eryximachus' speech, “noble
Eros" educates the opposites, making them agree. The difference between "noble Eros" and "base Eros" lies in education that is based on sophrôsynê, temperance, in opposition to pleonexia, which constitutes "base Eros".

With regard to Plato's conception of justice as harmonious unity that emerges from the link between the parts of the soul and the parts of the city, where each performs its task, the dialogue of reference is obviously the Republic.

SOCR. Then isn't it appropriate for the rationally calculating element to rule, since it is really wise and exercises foresight on behalf of the whole soul; and for the spirited kind to obey it and be its ally? GLAUC. Of course. SOCR. Now, as we were saying, isn't it a mixture of musical and physical training that makes these elements concordant, tightening and nurturing the first with fine words and learning, while relaxing, soothing, and making gentle the second by means of harmony and rhythm? GLAUC. Yes, exactly. [...] SOCR. What about temperance? Isn't he temperate because of the friendly and concordant relations between these same things: namely, when both the ruler and its two subjects share the belief that the rationally calculating element should rule, and do not engage in faction against it? GLAUC. Temperance in a city and in a private individual is certainly nothing other than that. ${ }^{17}$ (Tr. C. D. C. Reeve)

In particular, this passage is central for understanding the passage of Eryximachus' speech we are analyzing: the harmonic and rhythmic action takes origin from the mixture (krasis) of music and gymnastics, but it is not limited to it. Education provided by the rational 
part, which knows the laws of temperance, is also needed.

As previously mentioned, these elements are present in Eryximachus' discourse (it is possible to mention here ho meta tês hybreôs eros, cited specifically in relation to seasons (188 a 7), and its continuous emphasis on caution and temperance) and also, more generally, in Greek medicine. Knowing the physical environment in a broad sense is crucial in order to know the human being and the conditions of health and disease. ${ }^{18}$ In the Hippocratic Airs, Waters and Places the healthy city is characterized by balanced seasons: such an equilibrium is the equivalent of moderation (metriotês), a state where there are not sudden changes (metabolê). Such changes are the ecological equivalent of hybris; excess in its moral dimension. In Plato, cosmological medicine takes on a philosophical meaning which pervades all fields of human activity, including ethics and politics. Arguably, Eryximachus' discourse is thus an expression of the Platonic tendency to translate onto the philosophical plane the implications of a model peri physeôs.

Corporeal illness, unhappiness, folly and the ignorance of the soul, disorder at a meteorological level, religious impiety, hybris from an ethical and political perspective, are expressions of an infraction of the harmonic law which regulates the universe. These aspects emphasize the necessity of a technique which is able to re-create harmony taking celestial harmony as a model.

The Timaeus is of fundamental importance in addressing the question concerning the practice of composing elements, in particular the theory of the mélange of the Same and the Different:

He combined the two kinds of substance - the one indivisible and never changing, and the other the divided and created substance of the physical world - into an intermediate, third kind of substance, and then again, in the case of both identity and difference, he likewise formed intermediates between, in each case, that aspect of them which is undivided and that aspect of them which is divided in the physical realm. Then he took these three ingredients and made out of them a single, homogeneous mixture, though getting difference to be compatible with identity took force, since difference does not readily form mixtures. But once he had mixed identity and difference with substance and created a single blend out of the three ingredients, he divided up the whole mixture again, this time into as many portions as he needed, with each portion being a blend of identity,difference, and substance. ${ }^{19}$

Harmony induces the Different, refractory to composition, to mix with the Identical. In fact, compositions in fact will be born from the union and subsequent subdivision in parts (through particular numerical proportions) of the Identical, the Different and the intermediate substance. Compositions are thus born from three elements, thanks to the primary harmonizing work of the Demiurge, who operates on the two opposite principles of the Same and the Different.

However, the harmonic technê cannot order everything once and for all. In the same way in which the Demiurge's act is a continuous series of exhortations to the chora, so in the narrative framework the doctor Eryximachus advises against excessive drinking (in other words, he gives the prescription and provides the motivations), but he needs to obtain the consent of the patient, who will subsequently decide 
freely. The text in fact emphasizes that everyone will drink as he pleases without getting drunk (176 e 1-3). Eryximachus presents himself thus as a free doctor, using the terminology of the well-known passage of the Laws (720 b 8-e 5) in relation to the difference between doctors who are free and doctors who are slaves.

Harmonic technê is thus always linked to the theme of moral responsibility: the philosopher is also doctor, musician and demiurge in his harmonizing activity. Accordingly, there is no primacy of the physical plane over the ethical one, or of the ethical over the physical, but - we could say, inspired by our theme - a reciprocal and harmonic relation.

\section{PLATO'S COSMOLOGICAL MEDICINE}

It is not obvious that what is expressed by Eryximachus represents a theory that can be ascribed to Plato, not only because of the role that his speech plays in the economy of the Symposium, but also due to a problem which is internal to the non-authorial writing characterizing Plato's work. However, I believe that a comparison with other dialogues can be fruitful in order to collect hints in favor of the consistency between Eryximachus' thesis and a cosmological view possibly developed by Plato. This view would not be reducible to a physical conception of reality but should be properly understood as the expression of a dialectical and erotic cosmos based on the composition of parts.

The cosmological significance of medicine is ascribed to Hippocrates by Plato himself in Phaedrus ${ }^{20} 270$ c1-7, when Phaedrus tells Socrates that not only the nature of the soul, but also that of the body cannot be known without knowing the nature of the Whole. Nevertheless, the assumption that a cosmological medicine plays an important role both in Plato and in the Hippocratic corpus is highly controversial.

What is meant by "Whole"? The interpretations - not only with respect to this passage of the Phaedrus, but also in relation to other Platonic texts (cf. especially the Parmenides) — are divided between understanding the "Whole" in a physical sense, thus as "universe", and understanding it in a logical or metaphysical sense. Personally, I follow Brisson's interpretation ${ }^{21}$ of the relationship between holon, pan and hen, an interpretation which allows us to understand the whole as "universe". In fact, I am convinced of the closeness between Plato's thought and pre-Socratic physics, even though in terms of a rewriting emphasizing the ethical aspect of the totality. From this perspective, cosmological medicine can take a "holistic approach", in the sense of considering the connection and the composition of the parts constituting the whole. The Platonic rewriting acts also in relation to "medicine" (as such), which cannot be intended only as care of the body but, in fact, develops as "harmonic technê" of the entire universe. In terms of the holistic approach developed by Plato, a key text is the Charmides. In the passage 155 e 5-157 c $6^{22}$ Socrates emphasizes that good doctors, in order to treat the eyes, also treats the head, and to do so they treat the entire body. Moreover, as a doctor of the soul, Socrates says that to educate Charmides to temperance it is first necessary to cure his headache. Therefore, in this passage too, we can notice how, for Plato, the creation of the right composition of parts assumes always an ethical and educational meaning, which allows us to establish a relation between the practice of the physician and the practice of the philosopher.

The holistic approach is also recalled in the usage of the Hippocratic word for equilibrium, eukrasia, literally "good mixture" which is used 
in Timaeus 24 c 6 in relation to the right combination of seasons, but not in Eryximachus' discourse, where the term used is harmonia, to emphasize how the right composition can occur only having as a context of reference the whole to which the parts belong. Plato uses in Eryximachus' discourse the word harmonia as, in my opinion, he aims to emphasize how this relation of proportion between different elements, typical of musical harmony, is present from a cosmological perspective in the combination of the seasons. Moreover, in the passage 188 a4, which concerns the seasons, Plato uses next to the word harmonia the term krasis, mixture, in order to recall not only Empedocles but also Hippocrates, and to emphasize how Hippocratic eukrasia assumes a philosophical meaning, whether or not conceived together with harmonia. In the Philebus musical harmony is realized through the combination of the Limited and the Limitless and - an aspect particularly relevant for our study - Socrates applies this concept to seasons.

SOCR. Now take high and low, fast and slow, indeterminate things-isn't the same true? It at once introduces a determinant and establishes perfectly the whole art of music. PROT. Very true. SOCR. Again, in the case of extremes of cold and heat its advent removes what is far too much and indeterminate and produces what is measured and commensurable. PROT. Yes indeed. SOCR. So the mixture of indeterminate factors and determinants is responsible for good climate and generally for everything we have that is fine. ${ }^{23}$

The harmony of opposites is connected by Eryximachus, however briefly, to divination and religious practice. In Timaeus 71 c3-d4 we find a reference consistent with this topic, concerning the mixture of opposites within the liver that enables the operation of divination during sleep: ${ }^{24}$

Alternatively, when some breath of mildness wafts down from the thoughts and paints the opposite kind of images on the surface of the liver, they afford a respite from bitterness by refusing to stir up or involve themselves with something alien to them. Instead, by exploiting the sweetness inherent throughout the liver for their own purposes, they straighten all its parts until they are free of distortions, wrinkles, and blockages, and they make the part of the soul that has been housed in the same part of the body as the liver gracious and cheerful, so that at night it can indulge in the modest entertainment of divination by dreams, which it has to rely on since it lacks the ability to reason and to apply intelligence. ${ }^{25}$ (Tr. J. C. B. Gosling)

This passage enables us to grasp how the law of harmony acts not only between elements but, as in this case, also between images and physical elements - sweet and bitter - that constitute the liver.

The theory of the right composition of elements is used also on another fundamental level, the level of discourse: we may mention, as significant examples of this intersection, the prayer addressed to Pan that concludes the Phaedrus (279 b 9-c 5) or, more generally, the theme of koinonia and symplokê in the Sophist. ${ }^{26}$ As already mentioned, the term homologia, which is typical of the dialogic-dialectical method of Plato, is used by Eryximachus to enable the transition from the physical to the ethical and dialectical plane. I therefore propose to understand "cosmological medicine" 
not so much as a specific discipline in the medical field but as a Platonic reworking of the holistic approach characterizing the medicine of his times. This reworking, by using a philosophical key, enables Plato to extend the paradigm of the right composition to all fields, from ethics to psychology and politics. "Cosmological medicine" represents therefore a practice characterizing the dialectical philosopher, who recognizes himself as the good doctor establishing the right proportion between the parts. ${ }^{27}$ The "medical" practice of the philosopher is therefore necessary against ethical and political disorder, which needs to be "cured" through a law of harmony. This law is embodied in the Good: in the Philebus (26 a 3-5), the Good performs the function of a good mixture so that the elements are well blended, insofar as, once again, an incorrect relation between elements causes the ruin of the whole within which they are contained.

\section{CONCLUSION}

The passages I have focused on in this article - it would be possible to mention and analyze many others - are in my opinion the sign of a general thematic concordance between Plato and some texts of the Hippocratic Corpus in relation to a "cosmological medicine". However, they also demonstrate - and this represents one main objective of this article an extraordinary inventiveness in the way Plato approaches this topic from a philosophical perspective. This shift takes place already in Eryximachus' speech, ${ }^{28}$ which, if read against the background of the Timaeus, enables us to grasp the holistic approach characterizing Plato's philosophy, as well as the need for a harmonic technê, understood from a perspective of ethical responsibility. Plato's effort in detecting and incrementing the philosophical meaning of medicine testifies his will to guarantee the epistemic primacy of philosophy and therefore to create a certain dependency of medicine on philosophy, precisely what Hippocrates sought to avoid. ${ }^{29}$ Re-evaluating Eryximachus' discourse in this light enables us also to verify the positive role of his character and his discourse in the interpretation of the Symposium.

\section{BIBLIOGRAPHY}

Ayache 2002: L. Ayache, 'Hippocrate, l'ultime recours contre Socrate (Phèdre, 270c)', in M. Dixsaut, A. Brancacci, A. (eds.), Platon, source de présocratique: exploration, Vrin, Paris 2002, 151-167.

Barker 2000: A. Barker, 'Timaeus on music and the liver', in M. R. Wright (ed.), Reason and Necessity. Essays on Plato's Timaeus, Duckworth, London 2000, 85-99.

Brisson 2002: L. Brisson, 'Is the world one? A new interpretation of Plato Parmenides', Oxford Studies in Ancient Philosophy, 22 (2002), 1-20. - 1998: L. Brisson, Le Même et l'Autre dans la structure ontologique du Timée de Platon. Un commentaire systématique du Timée de Platon, Academia Verlag, Sankt Augustin 1998.

- 1994: L. Brisson (ed.), Platon, Parménide, GF-Flammarion, Paris 1994.

Bontempi 2009: M. Bontempi, L'icona e la città. Il lessico della misura nei dialoghi di Platone, Vita e Pensiero, Milano 2009.

Boussolas 1960: N. Boussoulas, 'Étude sur l'esthétique de la composition platonicienne des mixtes', Revue de Métaphysique et de Morale, 65.4 (1960), 422-448.

Bury 1909: R. G. Bury, The Symposium of Plato, W. Heffer and Sons Ltd, Cambridge 1909.

Candiotto 2015a: L. Candiotto, 'La legge dell'armonia nella composizione degli elementi, tra immanenza e trascendenza. Platone interprete di Eraclito', «EPEKEINA. International Journal of ontology», vol. 6,2 (2015, 1-12). 
- 2015b: L. Candiotto, 'Platone e la metafisica delle relazioni', in L. Candiotto (ed.), Senza dualismo. Nuovi percorsi nella filosofia di Platone, Mimesis, Milano-Udine 2015, 73-93.

2013: L. Candiotto, 'Socrate: il dialogo come farmaco', in L. Candiotto, L. V. Tarca (eds.), Primum Philosophari. Verità di tutti i tempi per la vita di tutti i giorni, Mimesis, Milano-Udine 2013, 47-60.

2011: L. Candiotto, 'The Children's Prayer: saving the Phenomena in Plato's Sophist', "ANAIS DE FILOSOFIA CLÁSSICA», vol. V n. ${ }^{\circ}$ 9, 2011, 77-85. http://www.ifcs.ufrj.br/ afc/

Cambiano 1991: G. Cambiano, Platone e le tecniche, Laterza, Roma 1991.

Casertano 2003: G. Casertano, 'Cause e concause', C. Natali, S. Maso (eds.), Plato physicus. Cosmologia e antropologia nel Timeo, Adolf Kakkert Editore, Amsterdam 2003, 33-63.

Cooksey 2010: T. L. Cooksey, Plato's Symposium: A Reader's Guide, Continuum, London-New York 2010.

Craik 2001: E. M. Craik, 'Plato and Medical Texts: Symposium 185c-193d', "The Classical Quarterly», New Series, 51, 1 (2001), 109-114.

Corrigan, Glazov-Corrigan 2004: K. Corrigan, E. Glazov-Corrigan, Plato's dialectic at play. Argument, structure, and myth in the Symposium, The Pennsylvania State University Press, University Park 2004.

Dover 1980: K. Dover, Plato: Symposium, Cambridge University Press, Cambridge 1980.

Edelstein 1945: L. Edelstein, 'The Rôle of Eryximachus in Plato's Symposium', Transactions and Proceedings of the American Philological Association, Vol. 76 (1945), 85-103.

Fronterotta 2013: F. Fronterotta, Eraclito. Iframmenti, Bur Rizzoli, Milano 2013.

Gaudin 1970: C. Gaudin, 'Remarque sur la météorologie de Platon', «Revue des Études anciennes», 72 (1970), 332-343.

Gordon 2012: J. Gordon, Plato's Erotic World. From Cosmic Origins to Human Death, Cambridge University Press, Cambridge 2012.

Hunter 2004: R. Hunter, Plato's Symposium, Oxford University Press, New York 2004.

Jouanna 1996: J. Jouanna, Euvres complètes: Airs-Eaux-Lieux, tome II, Les Belles Lettres, Paris 1996.

- 1974: J. Jouanna, Hippocrate. Pour une archéologie de l'école de Cnide, Les Belles Lettres, Paris 1974.
- 1961: J. Jouanna, «Présence d’Empédocle dans la Collection Hippocratique», «Bulletin de l'Association Guillame Budé», 4 (1961), 452-463.

Konstan 1982: D. Konstan - E. Young-Bruehl, «Eryximachus' Speech in the Symposium", «Apeiron», 16 (1982), 40-46.

Levin 2009: S. B. Levin, “Eryximachus' Tale: The Symposium's Role in Plato's Critique of Medicine”, «Apeiron», 42 (2009), 275-308.

Lloyd 1978: G. E. R. Lloyd (ed.), Hippocratic Writings, Penguin Classics, New York 1978.

Longrigg 1993: J. Longrigg, Greek rational medicine. Philosophy and medicine from Alcmeon to the Alexandrians, Routledge, London and New York 1993.

Macé 2005: A. Macé, 'L'uniforme et le non-uniforme» Schèmes empiriques de la pratique médicale dans la physique platonicienne', "Archives de Philosophie», 68 (2005), 223-239.

McPherran 2006: M. L. McPherran, 'Medicine, Magic, and Religion in Plato's Symposium', in J. H. Lesher, D. Nails, F. C. C. Sheffield (ed.), Plato's Symposium: Issues in Interpretation and Reception, Center for Hellenic Studies, Washington 2006, 71-95.

Migliori 2013: M. Migliori, Il disordine ordinato. La filosofia dialettica di Platone. I. Dialettica, metafisica e cosmologia; II. Dall'anima alla prassi etica e politica, Morcelliana, Brescia 2013.

O'Brien 2007: D. O'Brien, 'Aristophanes' speech in Plato's Symposium: the Empedoclean background and its philosophical significance', in A. Havlíček, M. Cajthaml, Plato’s Symposium. Proceedings of the Fifth Symposium Platonicum Pragense, OYKOYMENH, Prague 2007.

- 2005: D. O’Brien, 'Le Parménide historique et le Parmenide de Platon', in A. Havlíček, F. Karfik (eds.), Plato's Parmenides, OYKOYMENH, Prague 2005, 234-256.

Pelosi 2010: F. Pelosi, Plato: on Music, Soul and Body, Cambridge University Press, Cambridge 2010.

Robin 1929: L. Robin, Le Banquet, Les Belles Lettres, Paris 1929.

Rosen 1987: S. Rosen, Plato's Symposium, Yale University Press, New Heaven 1987.

Rowe 1999: C. J. Rowe, 'The Speech of Eryximachus in Plato's Symposium', in J. J. Cleary (ed.), Traditions of Platonism: Essays in Honour of John Dillon, Ashgate, Asleshot 1999, 53-64.

Temkin - Temkin 1987: C. L.,Temkin, O. Temkin (ed.), Ancient Medicine: Selected Papers of Ludwig Edelstein, John Hopkins University Press, Baltimore and London 1987. 
Thivel 2004: A. Thivel, 'Eryximaque et le principe des contraires', «Estudios griegos e indoeuropeos», 14 (2004), 35-44.

Van der Eijk 2012: P. Van der Eijk, (ed.), Greek Medicine by Jacques Jouanna, Brill, Leiden-Boston 2012. - 2005: P. Van der Eijk, Medicine and Philosophy in Classical Antiquity. Doctors and Philosophers on Nature, Soul, Health and Disease, Cambridge University Press, Cambridge 2005.

Vegetti 1995: M. Vegetti, La medicina in Platone, Il Cardo, Venezia 1995.

Wardy 2002: R. Wardy, 'The Unity of Opposites in Plato's Symposium', "Oxford Studies in Ancient Philosophy», 23 (2002), 1-61.

Wersinger 2001: A.-G. Wersinger, Platon et la dysharmonie: recherche sur la forme musicale, Vrin, Paris 2001.

Wunenburger 1976: J. J. Wunenburger, 'La dynamique Éraclitéenne des contraires et la naissance du mobilisme universel selon Platon', «Les Études philosophiques», 1 (1976), 29-47.

\section{NOTES}

${ }^{*}$ I'm grateful to the organisers of the X Symposium of the International Plato Society (IPS): The Symposium, Pisa University, July 2013, for having given me the opportunity to present a previous version of this paper and to all the participants with whom I had the chance to discuss it.

\section{Cf. also Plat., Symp. 177 a.}

2 Bury 1909, Robin 1929, Dover 1980, Rosen 1987, Nehamas 1989.

$3 \quad$ For example Corrigan 2004.

$4 \quad$ In line with Edelstein 1945, Konstan and

Young-Bruehl 1982, Rowe 1999, Hunter 2004, McPerrhan 2006, Cooksey 2010.

$5 \quad$ In this division, I am following Bury 1976.

6 Regarding the complex primal intertwining between philosophy and medicine, classical literature establishes the supremacy of philosophy over medicine (Edestein 1987, Cambiano 1991), whilst a reading which emphasizes the foundational contribution of medicine towards philosophy has been advanced in more recent years. To frame Eryximachus' speech within this context, and for an historical overview of the dissemination of medical material in the late fifth and early fourth century, cf. Craik 2001

$7 \quad$ Hippocrates has been cited in Prot. 311 b-c, Phaidr. 270 c-d, Charm. 156 e.

8 In this paper I emphasize the physical essence of these two forces, considering them as divergent physi- cal tendencies. Nevertheless, the forces in question can be meaningfully understood also from an ethical point of view, as epithymia and philia, as pursued by Konstan and Young-Bruehl (1982).

9 Plat., Symp. 187 a 3-b 6.

10 Giovanni Casertano emphasizes human

responsibility in the achievement of an ethical cosmos through never-ending acts of persuasion of matter. Cf. Casertano 2003. From another point of view, Nicolas

Boussoulas stresses the aesthetic dimension of erotic acts of composition, understood as sexual union. Cf. Boussoulas 1960 . For a more contemporary interpretation of the Plato's erotic cosmos, and for a detailed bibliography about the topic, cf. Gordon 2012.

11 Plat., Symp. 187 b6-cl.

12 Plat., Symp. 187 c8-d4.

13 Plat., Tim. 47 c7-e2.

14 Starting from a lexicological analysis, Luc Brisson underlines this aspect, showing deep connections between physical and ethical matter. Cf. Brisson 1998. Following Brisson, and deepening the analysis on the connection between philosophy and medicine, Arnaud Macé emphasizes the role of the philosopher as the physician of the soul. Cf. Macé 2005. About the use of the mathematical notion of proportion applied to the ethical and political practice of the law in the city, cf. Bontempi 2009.

15 Thivel 2004 questions whether Eryximachus' theory is to be considered mainly as a theory of the opposites, arguing for the preeminence of the theory of the similar in his discourse.

16 Instead of considering the Platonic description of Heraclitus as stereotyped (for this traditional thesis see, for example, Wunenburger 1976), Robert Wardy proposes an Heracleitean reading of the whole dialogue, which starts exactly from the lines we are analyzing and points out their connections with other speeches, especially the speech of Pausanias (cf. Wardy 2002). I will present my position about the Platonic interpretation of Heraclitus in Candiotto 2015a where I underline the different conceptions of the two philosophers in relation to the law that must rule the movement between the opposites: immanent to the elements for Heraclitus, transcending them for Plato. The difference between the two philosophers can be grasped also by focusing on the essence of this law, one conflictual and the other harmonic. Regarding this aspect, cf. Fronterotta 2013, p. 56.

17 Plat., Rep. IV 441 e 8-442 d 3.

18 Ludwig Edelstein individuates the general atmosphere of Eryximachus' encomium in the Hippocratic text On the Art, cf. Edelstein 1945, 90. David Konstan and Elisabeth Young-Bruehl in the Hippocratic text On Regimen, cf. Konstan and Young-Bruehl 1982, 42.

19 Plat., Tim. 35 a 1-b 6.

20 About the polemical references to Hippocrates in the Phaedrus, made by Phaedrus contra Socrates, see Ayache 2002. I agree that the polemical topic was the autonomy of the arts, but I would further this thesis in 
order to enlighten the Platonic strategy to establish the primacy of philosophy.

21 Cfr. Brisson 1994, 20-23, 43-73; Brisson 2002. This interpretation was criticized by O'Brien 2005.

22 For a more detailed analysis of this passage, cf. Candiotto 2013 where I describe Socrates as the true medician.

23 Plat., Phil. 26 a 2-b 4.

24 Barker 2000.

25 Plat., Tim. 71 c3-d4.

26 For my interpretation on the topic cf. Candiotto 2011 and Candiotto 2015b.

27 The interpretation of Plato delineated by the researches of Maurizio Migliori - now abridged in Migliori 2013 - is especially relevant for the theme of the dialectic composition of parts.

28 Accordingly, he does not represent the model of doctor which Plato seeks to oppose. Leven (2009) and others do not agree with this perspective, basing their thesis on the Platonic critique of the technai.

29 Cambiano 1991, 41. 